\title{
Local and International Factors Affecting Participation of Tanzanian Small and Medium Enterprises in Market Opportunity Brought by the African Growth and Opportunity Act (AGOA)
}

\author{
Edward Simon ${ }^{1}$, Emmanuel Munishi $^{2} \&$ Dickson Pastory ${ }^{3}$ \\ ${ }^{1}$ College of Business Education, Dar es Salaam Campus, Tanzania \\ Correspondence: Dr Emmanuel Munishi, College of Business Education, Dar es salaam, Tanzania.
}

Received: October 13, 2021

Accepted: December 13, 2021

Online Published: December 20, 2021

doi:10.5539/ijef.v14n1p68

URL: https://doi.org/10.5539/ijef.v14n1p68

\begin{abstract}
The study aimed at assessing local and international factors that affect participation of Tanzanian Small and Medium enterprises in market opportunity brought by African Growth and Opportunity Act (AGOA). The study focussed on Tanzania local SMEs engaged in garments and textiles, handicrafts, leather goods, footwear and agro-processing subsectors. The study utilized mixed approach methods and involved a total of 129 respondents. Questionnaire and interview were the main tools for data collection. Information was collected from the owners and marketers of SMEs located in Dar es Salaam, the officials of Ministry of Industry and Trade as well as the Tanzania Ministry of foreign Affairs and East Africa Cooperation. Quantitative data was analysed using SPSS software and qualitative data was examined using MAXQDA software. Findings revealed that both local and international related factors were inhibiting Tanzanian SMEs from engaging in the AGOA market. Such factors have been narrated in this paper and recommendations have been given in order to increase engagement of Tanzanian SMEs in the AGOA market.
\end{abstract}

Keywords: Small and Medium Enterprises (SMEs), African Growth and Opportunity Act (AGOA)

\section{Background Information}

Internationalization of Small and Medium local firms facilitates both individual livelihood and national economic development in any country. As one way of accessing international market; Governments of developing countries have been entering into international trade economic cooperation forums and agreements with developed government (Luostarinen, 1994). One such example of trade agreement, which is practiced by many African nations, is African Growth and Opportunity Act (AGOA) of the United State of America (USA) and Sub-Sahara Africa (SSA) countries (Dzidzornu, 2017).

AGOA started in the year of 2000 when it was officially enacted by the congress of the United State of America (USA) as part of Trade and Development Act of USA (Matto et al., 2012; Brenton \& Hoppe, 2016). The AGOA was enacted in order to provide a special motivation and window for trade between the USA and Sub-Saharan African (SSA) countries (Brenton \& Hoppe, 2016). The main objective of this Act is to increase trade volume as well as investment relationships between the USA and SSA, to expand and encourage economic growth, regional integration, as well as to assist the integration of SSA countries into the global economy (Osei-Assibey, 2015).

The Act emphasizes political stability and government reforms, improve access to USA credit and access to USA technology among African countries, offers export duty free to USA for the eligible products and institutes a high-level dialogue on trade and investment between USA and SSA in the form of Trade and Economic Forum (Mueller, 2018). On the other hand, to USA, the Act warrants provision of better market opportunities for the USA products in SSA, contributes to better commercial partnership between USA investors as well as traders and African elites, provides opportunities for USA companies to acquire and operate African state owned enterprises and infrastructure projects under the concept of privatization and Public Private Partnership (PPP) (AGOA, 2013; Opoku, 2016).

AGOA is categorized into two phases notably the first phase in 2000-2015 and second phase from 2015-2025. Under AGOA-I eligible products to export to USA were textile products, leather products, wood products, agricultural products and food stuff. In the AGOA-II mineral and energy products (i.e. oil and gas) were added among eligible products to be exported to USA by AGOA eligible countries (Opoku, 2016; World Bank, 2016). 
No restrictions have been placed on SMEs to access the USA market under AGOA. But SMEs wishing to sell goods in the United States through AGOA are required to obtain business visas from the USA embassy in their home countries and a full business registration depending on the country concerned (Mueller, 2018).

Currently, there are 38 SSA countries eligible in AGOA market. These are Angola, Botswana, Cape Verde, Comoros, Ethiopia, Guinea, Ivory Coast, Lesotho, Madagascar, Mali, Mauritius, Namibia, Nigeria, Sao Tome, South Africa, Togo, Zambia, Benin, Burkina Faso, Cameroon, Chad, Congo, Djibouti, Gabon, Ghana, Guinea Bissau, Kenya, Liberia, Malawi, Mauritania, Mozambique, Niger, Rwanda, Senegal, Sierra Leone, Tanzania, and Uganda (Mueller, 2018).

Tanzania signed this trade agreement in 2000 (since the beginning of AGOA-I) in order to improve trade relations with USA and improve its international market value (Seyoum, 2017). In 2016, the government come-up with the strategic plan known as "Tanzania National AGOA Strategy" that identifies four strategic subsectors/areas to rapidly develop and increase participation of Tanzanians in AGOA market. The first strategic area is garments and textile, second area is the agro-processing industry which includes edible nuts, flowers, fruits, spices and horticultural products; third area is the leather goods and footwear; fourth area is handicrafts which include home decor and accessories (Tanzania National AGOA Strategy, 2016). All these strategic areas can utilize natural resources which are locally produced as well as include both male and female entrepreneurs from both rural and urban areas.

Moreover, the USAID has been working to improve competency of the Tanzanian entrepreneurs through awareness creation about AGOA as critical efforts towards assisting Tanzanian entrepreneurs to access this important market (Kazimoto, 2014; USAID, 2019). But, existing data show that Tanzania has not benefited significantly from the AGOA trade as compared to other AGOA eligible counterparts notably Kenya and Uganda in the Eastern zone of Africa. From 2015 to 2019, Tanzania exported goods worth US\$ 121 million to USA under AGOA. Uganda and Kenya exported to the USA goods worth US\$ 169 and US\$ 601 million respectively in the same period. Under the same period, the exports of Angola and South Africa to USA worth an average of US\$ 2,382 and US\$ 7,620 million respectively. Table 1 illustrates exportation statistics of six selected countries from 2015 to 2019.

Table 1. Total exports of selected countries to the USA under AGOA (in Million US\$)

\begin{tabular}{lcccccc}
\hline Countries & $\mathbf{2 0 1 5}$ & $\mathbf{2 0 1 6}$ & $\mathbf{2 0 1 7}$ & $\mathbf{2 0 1 8}$ & $\mathbf{2 0 1 9}$ & Average \\
\hline Rwanda & 46 & 26 & 44 & 67 & 56 & 48 \\
Tanzania & 105 & 149 & 124 & 97 & 130 & 121 \\
Uganda & 164 & 151 & 179 & 169 & 180 & 169 \\
Kenya & 573 & 552 & 572 & 643 & 667 & 601 \\
Angola & 2,806 & 2,856 & 2,603 & 2,698 & 955 & 2,384 \\
South Africa & 7,314 & 6,759 & 7,759 & 8,470 & 7,799 & 7,620 \\
\hline
\end{tabular}

Source: https://agoa.info/profiles (Accessed 15th April 2020).

AGOA trade is dominated by very few SSA countries; these are Gabon, Nigeria, Angola and South Africa which together account for over $80 \%$ of the products exported to USA under AGOA. East African countries (Tanzania, Rwanda Kenya and Uganda) altogether make $11 \%$ of the products exported under AGOA; in which Kenya alone represents about $65 \%$ of the goods exported from the region (Seyoum, 2017). Hence the remaining 35\% of the East Africa regional exported is shared between Tanzania, Uganda and Rwanda. The Kenyan regional share in AGOA is significantly high and is still growing. If Tanzania will not closely consider this market share gap in AGOA market; the little share it has will be engulfed by its competitors.

Tanzanian entrepreneurs have not utilized benefits offered by AGOA to the meaningful extent. Failure to exploit this market may increase problem of low job creation and low revenue in the country. Nevertheless, most literature on AGOA have been dedicated on its impact to the SSA eligible countries, undue focus lies on the extent to which SSA countries have benefited from AGOA and how it affects the economy of USA. Less has been written on factors inhibiting successful participation of some countries, like Tanzania, in AGOA market. Thus paper analysed local and international inhibiting factors for the Tanzanian SMEs to effectively participate in AGOA market.

\section{Literature Review}

\subsection{Small and Medium Enterprises in Tanzania}

According to Amoafo (2012) there is no universal definition for Small and Medium Enterprises (SMEs) since the 
definition depends on who is defining it and where it is being defined. SMEs can be defined in two ways; based on the number of employees in an enterprise and/or based on the total fixed assets of the enterprise. In Tanzania's context; a small enterprise has between 5 and 49 workers with capital of between 5 million and 199 million. A medium enterprise has between 50 and 100 workers with capital of 200 million to 800 million (The United Republic of Tanzania SMEs Development policy, 2003).

Table 2. Classification of SMEs in Tanzania

\begin{tabular}{lll}
\hline Category & Employees & Capital Investment (in TZS) \\
\hline Micro Enterprises & $1-4$ & Up to 5 Million \\
Small Enterprises & $5-49$ & Above 5 Million to 200 Million \\
Medium Enterprises & $50-99$ & Above 200 Million to 800 Million \\
Large Enterprises & $100+$ & Above 800 Million \\
\hline
\end{tabular}

Source: Tanzanian SME Policy of 2003.

\subsection{Factors Affecting SMEs' Participation in International Markets}

A study conducted in Benin and Togo found AGOA has insignificant impact to the SMEs development. This was due to the weak capacity of local entrepreneurs to fully exploit market opportunity offered by AGOA. The study informed that lack of government support in terms of capital and other supportive programs to the local entrepreneurs, as well as poor physical infrastructure in these countries were the main constraints for entrepreneurs to fully exploit trade opportunities presented by AGOA (Zappile, 2011 cited in Adetoso \& Akinseluse, 2016).

Most of SSA countries do not have clear cut implementation policies and strategies for AGOA (Seyoum, 2017). Implementation of individual National AGOA policy and strategies in SSA countries has been done in ad-hoc manner without considering strategic development plans of the country. As the results, the SSA countries are not benefiting from the AGOA; but rather, USA is the one benefiting from the trade through expansion of its economic and trade zone as well as through establishment of its military bases in Africa for its security purpose (Asante et al., 2016)

In order to enjoy the benefits of the AGOA, governments of eligible countries are supposed to formulate business policies that empower their SMEs to engage in integration businesses. This includes establishment of policies which facilitate availability of natural raw resources in sustainable manner, policies that encourage opening of new businesses and investment, construction of the good roads and railways which connect all part of the country to the seaports and improvement of communication channels in the country (Mueller, 2018).

Low level of education/skills and financial limitation has been reported as the root causes of underdeveloped Tanzania SME sector to the international level (Msemo, 2013). Other popular mentioned factors are technological barrier (i.e. In ability to use emerging communication technologies like websites, social media, online discussion forums and other online channels), high price of the fuel and frequently power outages and lack of capital assistance from financial institutions (Yahya \& Mutarubukwa, 2015).

The following have been suggested to help local Tanzanian small producers to market in the international markets:- development of national political vision that support SMEs business, identification of priority areas for SMEs to develop, stimulation of e-government in all sectors, establishment of programs that improve e-security, improvement of technological infrastructure and provision of government grants to support small firms (Yahya $\&$ Mutarubukwa, 2015). Stable power supply in the country and good roads networks (Msemo, 2013).

\subsection{Conceptual Framework}

The paper aim was to establish both local and international factors affecting participation of Tanzanian Small and Medium enterprises in AGOA market. The conceptual framework to model the whole idea of this paper was given as shown in the figure 1. In the model, the study assumed that there was relationship between SMEs engagement in international markets (specifically AGOA market) and both local and international factors in the sphere of entrepreneurship. However, there is interlinking between local and international factors in supporting internationalizations of SMEs.

Local factors assessed were availability of additional capital, technological support, bureaucracy in accessing permits and licences, technological infrastructure in the country, business related policies in the country, level of business security and provision of business information in the country. Meanwhile international factors were bureaucracy in accessing international immigration and export permits, business security at international level, as well as existing level of diplomatic relationship. 


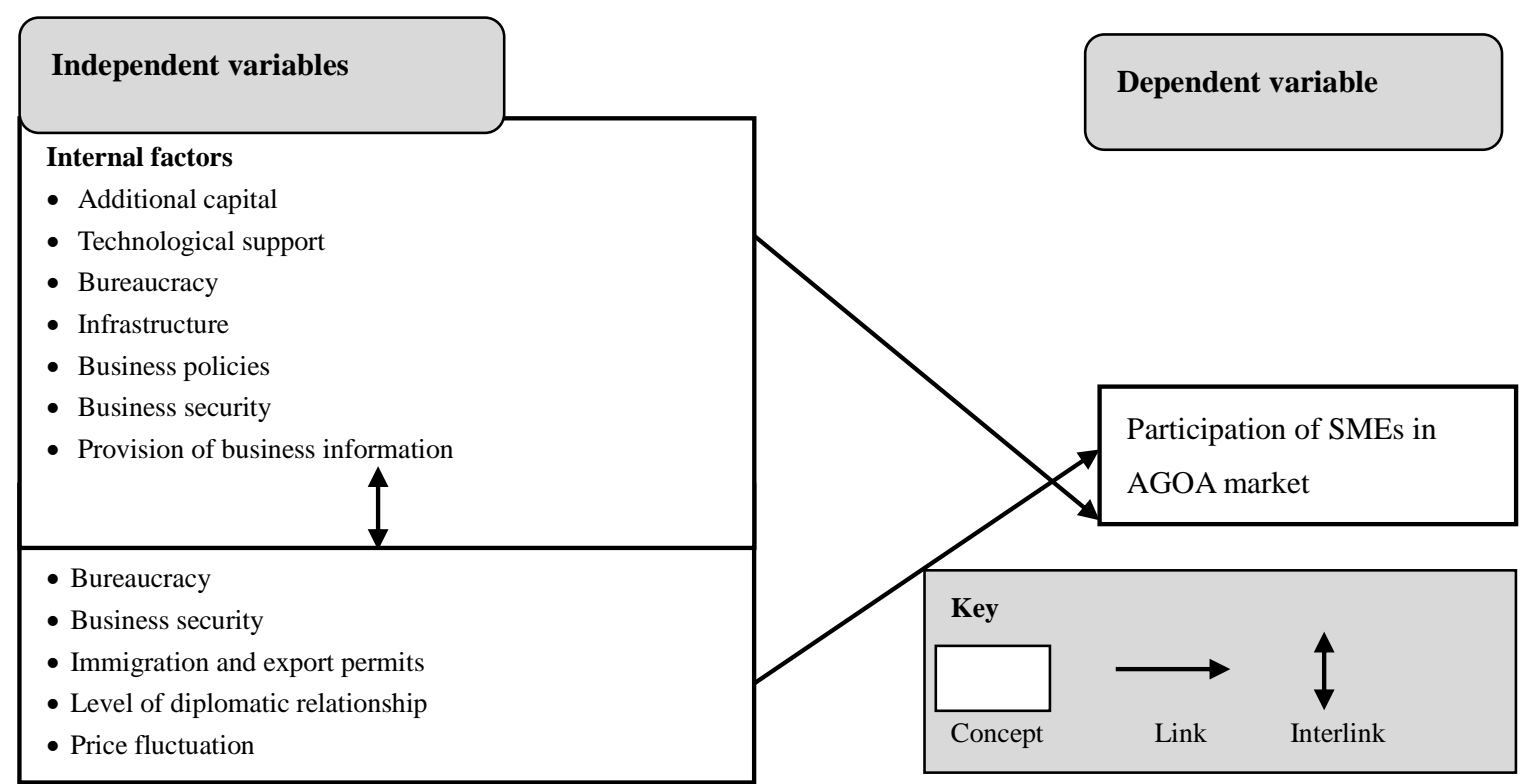

Figure 1. Conceptual framework of the study

\section{Methodology}

\subsection{Research Approach}

Mixed research approach was adopted, in which, both quantitative and qualitative approaches were applied simultaneously. Quantitative approach was useful in enumeration of the respondents' perspectives; hence, the extent to which the studied factors affect involvement of SMEs in AGOA market was quantified using quantitative methods. Meanwhile, qualitative approach enabled researcher to clarify (give reason behind) the obtained quantitative results. Furthermore, a qualitative approach was useful in determining what should be considered or adopted in order to increase engagement of Tanzania local SMEs in AGOA market.

\subsection{Research Design}

Descriptive research design was used since it was a good design to portray an accurate profile of the SMEs, their business operations as well as associated supportive and hindering factors. This design helped researcher to have clear picture of the factors that affect participation of Tanzania local SMEs in AGOA-market.

\subsection{Participants}

The study was conducted in Dar es Salaama; the commercial city of Tanzania. The city encompassed large number of SMEs compared to the rest of regions in Tanzania. Participants in the study comprised managers and marketers of the randomly sampled 60 SMEs. Contacts of the sampled SMEs were obtained from headquarter of Small Industry Development Organization (SIDO) in Dar es Salaam. SMEs selected were those dealing with garments and textiles, handicrafts, leather goods and footwear as well as agro-processing. On the other hand officials of Tanzania Ministry of Trade and Industry as well as Tanzania Ministry of foreign Affairs and East Africa Cooperation were selected through convenience sampling technique. In each selected SME, one director and one marketer were selected; therefore, the paper had 120 individuals from sampled 60 SMEs. 10 officials were selected at the Ministry of Trade and Industry and 9 officials at the Tanzania Ministry of foreign Affairs and East Africa Cooperation. Altogether, the study selected 130 individuals.

\subsection{Data Collection and Analysis}

The study used only primary data that were collected via questionnaire and interview. Managers and marketers of the sampled SMEs were subjected to both questionnaire method of data collection while government officials from the ministries were subjected to both questionnaires and interviews. The main questions in the questionnaires had Likert scale response mode that ranged from $1=$ strongly disagree to $5=$ strongly agree. Thematic analysis was used to analyse qualitative data while descriptive and regression analyses were used for quantitative data. In interpret quantitative results; the mean score were interpreted as shown in the table 3. 
Table 3. Interpretation of the mean scores

\begin{tabular}{ll}
\hline Mean scores & Interpretation \\
\hline $4.21-5.00$ & Very high inhibiting factor \\
$3.41-4.20$ & High inhibiting factor \\
$2.61-3.40$ & Moderate inhibiting factor \\
$1.81-2.60$ & Low inhibiting factors \\
$1.00-1.80$ & Very low inhibiting factors \\
STD $>1.5$ & Indicate significance variation \\
\hline
\end{tabular}

\section{Respondents Profile}

\subsection{Sex of Respondents}

Gender data of the selected managers and marketers of the sampled SMEs together with that of selected government officials from the mentioned ministries were presented as shown in the table 4. Male respondents involved in the study were 79 in total whereby 66 males were entrepreneurs and 13 were government officials. Female respondents were 50 in total whereby 44 of them were entrepreneurs and 6 were government officials.

Table 4. Presentation of respondents by their genders

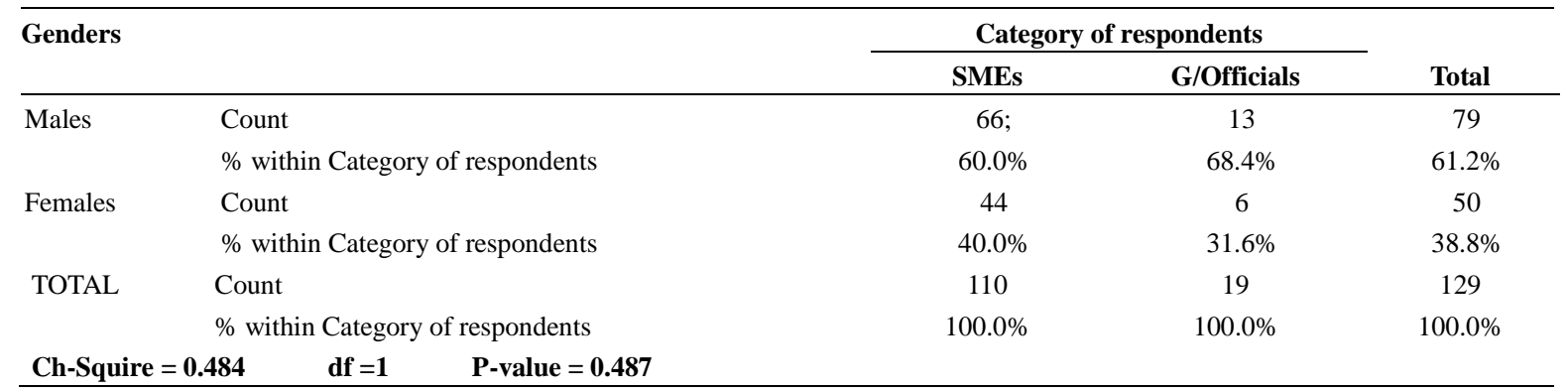

In percentage, male represented $61.2 \%$ of the entire respondents and female represented $38.8 \%$. However, such difference was insignificant since probability value was greater than 0.05 ( $\mathrm{p}$-value $=0.487$ ). This implied that the study contained nearly equal views of both males and females.

\subsection{Age Groups of Respondents}

The results in the Table 5 revealed that respondents aged between 21-30 years old represented 24\%, 31-40 years old represented $27.1 \%$, 41-50 years represented 28.7\%, 51-60 years represented $14.7 \%$ and those who were above $60 \%$ represented $5.4 \%$. However, p-value was 0.563 indicating no significant representation difference among the reviewed age groups. Hence, the study managed to collected views of the different age groups/generation almost equally.

Table 5. Presentation of respondents by their age groups

\begin{tabular}{|c|c|c|c|c|}
\hline \multicolumn{2}{|c|}{ Age groups } & \multicolumn{2}{|c|}{ Category of respondents } & \multirow{3}{*}{$\begin{array}{r}\text { TOTAL } \\
31\end{array}$} \\
\hline & & \multirow{2}{*}{$\begin{array}{c}\text { SMEs } \\
28\end{array}$} & \multirow{2}{*}{$\frac{\text { G/Officials }}{3}$} & \\
\hline $21-30 \mathrm{yr}$ & Count & & & \\
\hline & $\%$ within Category of respondents & $25.5 \%$ & $15.8 \%$ & $24.0 \%$ \\
\hline \multirow[t]{2}{*}{$31-40 \mathrm{yr}$} & Count & 30 & 5 & 35 \\
\hline & $\%$ within Category of respondents & $27.3 \%$ & $26.3 \%$ & $27.1 \%$ \\
\hline \multirow[t]{2}{*}{$41-50 \mathrm{yr}$} & Count & 30 & 7 & 37 \\
\hline & $\%$ within Category of respondents & $27.3 \%$ & $36.8 \%$ & $28.7 \%$ \\
\hline \multirow[t]{2}{*}{$51-60 y r$} & Count & 15 & 4 & 19 \\
\hline & $\%$ within Category of respondents & $13.6 \%$ & $21.1 \%$ & $14.7 \%$ \\
\hline \multirow[t]{2}{*}{$>60 \mathrm{yr}$} & Count & 7 & 0 & 7 \\
\hline & $\%$ within Category of respondents & $6.4 \%$ & $0.0 \%$ & $5.4 \%$ \\
\hline \multirow[t]{2}{*}{ TOTAL } & Count & 109 & 110 & 19 \\
\hline & $\%$ within Category of respondents & $100.0 \%$ & $100.0 \%$ & $100.0 \%$ \\
\hline \multicolumn{2}{|c|}{ Ch-Squire $=2.967 \mathrm{df}=4$} & & & \\
\hline
\end{tabular}




\subsection{Entrepreneurship Experiences of the Sampled SMEs}

Figure 2 shown entrepreneurs who had engaged in the entrepreneurship for the period of 4-6 years were 35.45\%; for the period of 7-9 years were $26.36 \%$; period of $10-12$ years were $20 \%$; period of $13-15$ years were $12.7 \%$ and period of 16 years and above were $5.4 \%$. There were many SMEs at the beginning of the Figure but very few at the end of the Figure. This reflects the concept which argued that many SMEs are created every day but majority die before reach maturity stage (Zaied, 2018).

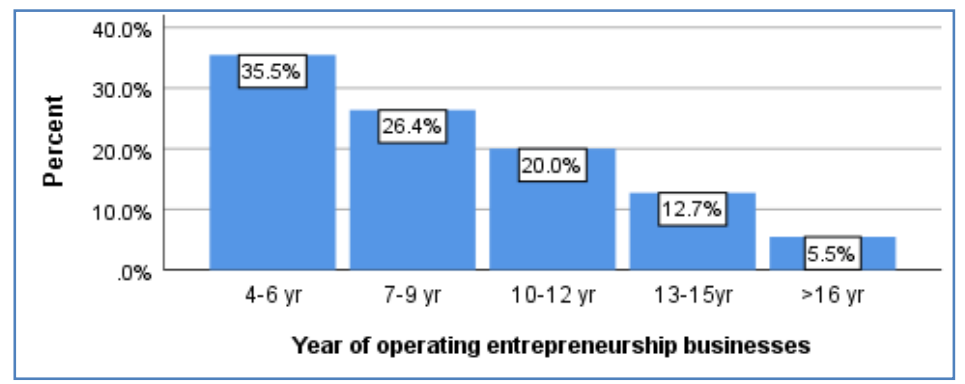

Figure 2. Presentation of SMEs by their entrepreneurship experiences

\subsection{Working Experiences of the Selected Government Officials}

The working experiences of the government officials in their respective ministries was captured and presented in the Figure 3.

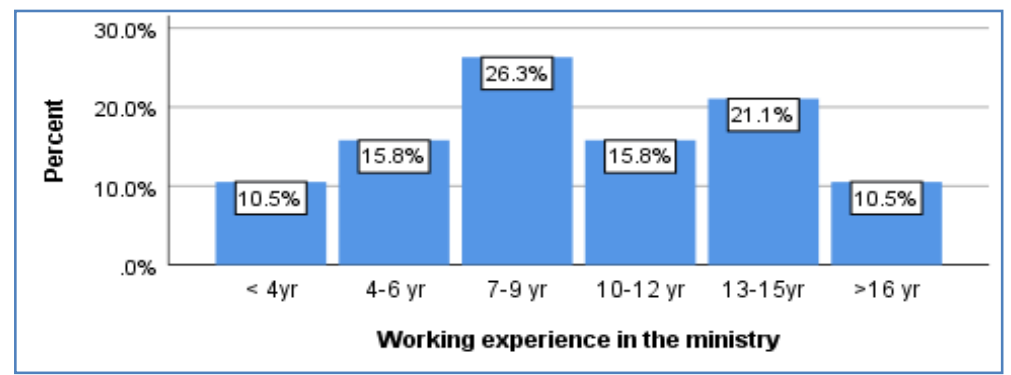

Figure 3. Presentation of government officers by their working experiences

Respondents (in Figure 3) who had worked for the period of less than 4 years presented $10.5 \%$ of all sampled government officials, those with experience of 4 to 6 years presented $15.8 \%, 7$ to 9 years presented 26.3\%, experience of 10 to 12 years presented $15.8 \%$, experience of 13 to 15 years presented $21.1 \%$ and those with experience of 16 years or more presented $10.5 \%$ of all government officials in the study. This statistics indicated that the study was able to capture data from experienced personnel who were welled informed concerning challenges face SMEs in the international markets, particularly AGOA market.

\section{Analysis of the Findings and Discussion}

\subsection{SMEs Engagement in AGOA}

Sampled SMEs were asked whether they had ever tried to engage in AGOA market; where they rated their answers as either "no; I have not tried" or "yes; but I did not succeed" or "yes and I succeeded". Figure 3 presented the results of this question. It was noted that majority (80\%) of the sample SMEs had never tried to do business in this market, $17.3 \%$ had tried but they did not succeeded while $2.7 \%$ had tried and succeeded. With this results, it can be generally accepted that majority of SMEs in Tanzania were not enjoying opportunities given by AGOA market. Hence, the study wanted to find out what were the main causes for the large percent of SMEs not to try this market as well as reason for failure among those who tried to push their businesses in AGOA market. This was attained through assessment of local and international factors that had effects on internationalization of the SMEs. 


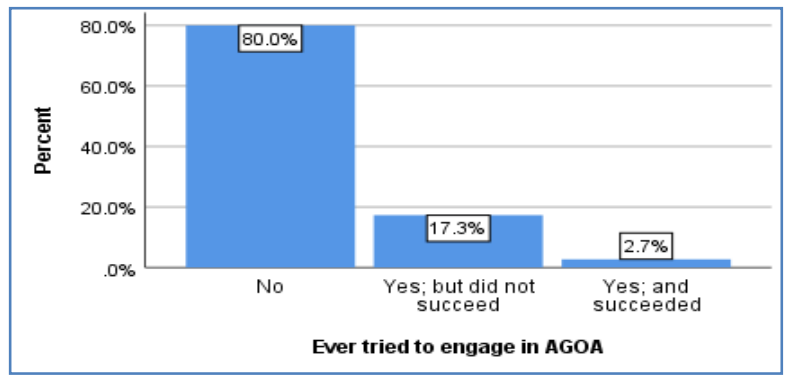

Figure 4. SMEs engagement in AGOA

\subsection{Local Factors Affecting SMEs}

The first objective focused on the analysis of local factors affecting Tanzanian SMEs from effectively participating in the AGOA market. Six questions were prepared and presented to the respondents to rate the extent they could agree with the statements/variables of the questions. The questions were answered by respondents from both SMEs and government institutions. The descriptive results were presented in the table 6 . It was mentioned that factors which highly inhibited or lowered the efforts of local SMEs to engage in the AGOA market were lack of technological support such as seminars on how to use technological equipment (mean $=3.48 \pm 1.021$ ), week business related policies in the country (mean= $3.44 \pm 0.980)$, low capital and lack of loans (mean $=3.43 \pm 1.251$ ). The remaining factors were noted to have moderate effect on thereof. These were long bureaucracy in accessing business permits and related government permits in Tanzania (mean=3.32 \pm 1.043 ), poor provision of business information in the country (mean=3.32 \pm 0.974 ) and poor infrastructures in the country (mean=3.22 \pm 1.239 ). The general results indicates local factors had moderate inhibiting effect (mean=3.36) to the SMEs engagement in AGOA market.

Table 6. Local factors affecting SMEs - descriptive analysis

\begin{tabular}{|c|c|c|c|c|c|}
\hline Factors & $\mathbf{N}$ & Min & Max & Mean & Std. \\
\hline Lack of technological support & 129 & 1 & 5 & 3.48 & 1.021 \\
\hline Week business related policies & 129 & 1 & 5 & 3.44 & 0.980 \\
\hline Low capital and lack of loans & 129 & 1 & 5 & 3.43 & 1.251 \\
\hline Long bureaucracy in accessing business permits & 129 & 1 & 5 & 3.32 & 1.043 \\
\hline Poor provision of business information & 129 & 1 & 5 & 3.32 & 0.974 \\
\hline Poor infrastructures in the country & 129 & 1 & 5 & 3.22 & 1.239 \\
\hline WEIGHTED MEAN & & & & 3.36 & \\
\hline
\end{tabular}

Correlation analysis was performed in order to finding out whether there was significant correlation between the mentioned local factors in inhibiting SMEs from engaging to the AGOA market (see Table 7). Accordingly, the six variables ware named as follows: LIF1 = Low capital and lack of loans; LIF2 = Lack of technological support; LIF3= Long bureaucracy in accessing business permits; LIF4= Poor infrastructures in the country; LIF5=Week business related policies; and LIF6=Poor provision of business information in the country.

Table 7. Local factors affecting SMEs - Correlation analysis

\begin{tabular}{|c|c|c|c|c|c|c|c|}
\hline Factors & & LIF1 & LIF2 & LIF3 & LIF4 & LIF5 & LIF6 \\
\hline LIF1 & $\begin{array}{l}\text { Pearson Correlation } \\
\text { Sig. (2-tailed) }\end{array}$ & 1 & & & & & \\
\hline LIF2 & $\begin{array}{l}\text { Pearson Correlation } \\
\text { Sig. (2-tailed) }\end{array}$ & $\begin{array}{l}.445^{* *} \\
.000\end{array}$ & 1 & & & & \\
\hline LIF3 & $\begin{array}{l}\text { Pearson Correlation } \\
\text { Sig. (2-tailed) }\end{array}$ & $\begin{array}{l}.475^{* *} \\
.000\end{array}$ & $\begin{array}{l}.466^{* *} \\
.000\end{array}$ & 1 & & & \\
\hline LIF4 & $\begin{array}{l}\text { Pearson Correlation } \\
\text { Sig. (2-tailed) }\end{array}$ & $\begin{array}{l}.385^{* *} \\
.000\end{array}$ & $\begin{array}{l}.513^{* *} \\
.000\end{array}$ & $\begin{array}{l}.575^{* *} \\
.000\end{array}$ & 1 & & \\
\hline LIF5 & $\begin{array}{l}\text { Pearson Correlation } \\
\text { Sig. (2-tailed) }\end{array}$ & $\begin{array}{l}.287^{* *} \\
.001\end{array}$ & $\begin{array}{l}.355^{* *} \\
.000\end{array}$ & $\begin{array}{l}.467^{* *} \\
.000\end{array}$ & $\begin{array}{l}.413^{* *} \\
.000\end{array}$ & 1 & \\
\hline LIF6 & $\begin{array}{l}\text { Pearson Correlation } \\
\text { Sig. (2-tailed) }\end{array}$ & $\begin{array}{l}.349^{* *} \\
.000\end{array}$ & $\begin{array}{l}.234^{* *} \\
.007\end{array}$ & $\begin{array}{l}.240^{* *} \\
.006\end{array}$ & $\begin{array}{l}.366^{* *} \\
.000\end{array}$ & $\begin{array}{l}.378^{* *} \\
.000\end{array}$ & 1 \\
\hline
\end{tabular}

**. Correlation is significant at the 0.01 level (2-tailed). 
The results revealed that there was strong positive significant correlation between all local factors assessed in this study. The p-values was significant at the level lower than 0.0001 for most of variables. This indicated that there was associating. With these results it can be concluded that local factors assessed in this study were significantly inhibiting ability of local SMEs to achieve AGOA market. Apart from that they were relating to each other in such a way that effect of one factor perpetuated effect of other factors.

Concerning weak business related policies in the country, the following were mentioned by interviewees:-

“...... a business man can be detained by polices for several days to provide information about his/her business as well as the cargo he is transporting; and they will not even consider the life span of the cargo. At the end of their investigations the whole cargo/products may have been expired and polices would not pay for the losses caused by them." (Interviewee 1; Sept 14, 2020).

".......the organizations and institutions that assist SMEs are weak following uncoordinated and fragmented partly due to a lack of clear policy and guidance for the development of this sector. As a result, the potential of SMEs in advancing the national economy appears to have been underutilized." (Interviewee 11; Oct 8, 2020).

"The sector-supporting initiatives (the programs) and actions have had a small impact. As a result, a number of gaps have developed, making it unable to address the key restrictions impeding development of SME sector......" (Interviewee 12; Oct 16, 2020).

"Our SME development policy does not talk about what can be done to protect SMEs from inflation and other macroeconomic challenges such as cost of borrowing and production. The new policy that will address some of the current challenges facing SMEs is still under construction...the challenges are credit facilities." (Interviewee 15; Oct 10, 2020).

Cornering low technological support there was interviewee who mentioned that

"......for the enterprise to develop, the owner had to regularly restructure its operation base on the technological advancement. He/she should always be in the moment of rethinking on how to keep pace with changes in technology and business operations. Apart from that government authorities should support entrepreneurs' efforts of adopting modern technological in order to increase their production abilities." (Interviewee 14; Oct 10, 2020)

The following were mentioned concerning low capital and shortage of loans:-

"Not only in Tanzania, but in the whole African, the SMEs pay the same fixed costs as large corporations to comply with laws. However, SMEs have severely limited access to local and international financing programs. As a result, their ability to promote their products internationally is constrained" (Interviewee 3; Sep 20, 2020).

"The government should consider ways to make financial rules and policies more flexible so that SMEs can flourish in the high competitive markets outside the country." (Interviewee 6; Sep 14, 2020).

"Government policies must create an environment that is conducive to the growth of SMEs, such as special tax, low-interest loans, and discounts. Setting up special funds for those who adhere to national development policies is an effective strategy." (Interviewee 10; Sep 27, 2020).

The following were mentioned during interview in relation to shortage of business information:-

"I agreed to the fact that most of us are not aware of the business opportunity you have just mentioned (the AGOA market). If we could know about it, most of entrepreneurs in Tanzania could try it..... I am now going to research about this AGOA market" (Interviewee 9; Sep 27, 2020).

"Entrepreneurs lack access to appropriate sources of business information as well as the expertise to find information. Aside from that, there is no umbrella organization for SMEs that can provide them with business information." (Interviewee 7; Sep 21, 2020).

"The government through its business agencies such as chamber of commerce and agriculture and responsible ministries have been publishing business information always. But, $i$ accept that the information accessible to SMEs has not been fully utilized by them due to the information gap on how to develop business relationships and industry requirements." (Interviewee 13; Oct 8, 2020).

In relation to poor infrastructure in the country the following were reported

"Better infrastructures are one of the most critical factors for the growth and development of entrepreneurs because they interact with the economy through production processes.........Poor road networks, inadequate portable water and electricity supply undermines development of entrepreneurship in the country." (Interviewee 2; Sep 14, 2020) 
"The gap in the availability of better transportation infrastructures in Tanzania has greatly impacted on the production processes within manufacturing sector. This has lowered ability of our SMEs to compete in the global market." (Interviewee 11; Oct 8, 2020)

"We have poor roads and highways even airport facilities are not enough to support faster shipping of goods within the country and to outside the country....." (Interviewee 4; Sep 15, 2020)

"I visited China three year back and saw how it was organized in terms of transport network and shipping activities. Those people have reason to be successful in selling their products in the international markets." (Interviewee 12; Oct 8, 2020)

\subsection{International Factors Affecting}

The second objective was to assess how international factors were affecting Tanzanian SMEs from effectively participating in the AGOA market. Six variables (adopted from the literature review) were used to collect data for this objective. Obtained data were subjected to the descriptive and correlation analyses. Results of descriptive analysis have been given in the Table 8 .

Table 8. International inhibiting factors - Descriptive analysis

\begin{tabular}{lccccc}
\hline Factors & N & Min & Max & Mean & Std. \\
\hline Rapid price fluctuation & 129 & 1 & 5 & & 3.75 \\
Higher quality standard established by AGOA & 129 & 1 & 5 & 3.70 & 1.064 \\
Long bureaucracy in access international permits from USA embassy & 129 & 1 & 5 & 3.52 & 1.009 \\
Weakness of Tanzania currency & 129 & 1 & 5 & 3.52 & 0.874 \\
Low level of diplomatic relation between Tanzania and USA & 129 & 1 & 5 & 3.37 & 1.246 \\
Threat of business security in the international market & 129 & 1 & 5 & 3.36 & 1.078 \\
WEIGHTED MEAN & & & & 3.54 \\
\hline
\end{tabular}

It was revealed that factors which could impose high challenges (the high inhibiting factors) were rapid price fluctuation (mean=3.751 \pm 1.064 ), higher quality standard established by AGOA (mean=3.70 \pm 1.009 ), long bureaucracy in access international permits from USA embassy (mean=3.52 \pm 1.094 ), weakness of Tanzania currency (mean $=3.52 \pm 0.874$ ). Meanwhile factors which were mentioned to have moderate inhibiting effects or challenges were low level of diplomatic relation between Tanzania and USA (mean $=3.37 \pm 1.246$ ) and threat of business security in the international market $(3.36 \pm 1.078)$. The general result indicated that international factors could highly stop Tanzania SMEs from effectively participating in the AGOA market.

In performing correlation analysis, the variables were abbreviated as follows:- IIF1= Long bureaucracy in accessing international permits from USA embassy; IIF2 = Threat of business security in the international market; IIF3= Low level of diplomatic relation between Tanzania and USA; IIF4= Weakness of Tanzanian currency; IIF5= Rapid price fluctuation; and IIF6= Higher quality standard established by AGOA. The result of such correlation analysis has been given in the table 9 .

Table 9. International inhibiting factors - Correlation analysis

\begin{tabular}{|c|c|c|c|c|c|c|c|}
\hline Factors & & IIF1 & IIF2 & IIF3 & IIF4 & IIF5 & IIF6 \\
\hline IIF1 & $\begin{array}{l}\text { Pearson Correlation } \\
\text { Sig. (2-tailed) }\end{array}$ & 1 & & & & & \\
\hline IIF2 & $\begin{array}{l}\text { Pearson Correlation } \\
\text { Sig. (2-tailed) }\end{array}$ & $\begin{array}{l}.443 \\
.000\end{array}$ & 1 & & & & \\
\hline IIF3 & $\begin{array}{l}\text { Pearson Correlation } \\
\text { Sig. (2-tailed) }\end{array}$ & $\begin{array}{l}.329 \\
.000\end{array}$ & $\begin{array}{l}.442 \\
.000\end{array}$ & 1 & & & \\
\hline IIF4 & $\begin{array}{l}\text { Pearson Correlation } \\
\text { Sig. (2-tailed) }\end{array}$ & $\begin{array}{l}.535 \\
.000\end{array}$ & $\begin{array}{l}.517 \\
.000\end{array}$ & $\begin{array}{l}.408 \\
.000\end{array}$ & 1 & & \\
\hline IIF5 & $\begin{array}{l}\text { Pearson Correlation } \\
\text { Sig. (2-tailed) }\end{array}$ & $\begin{array}{l}.458 \\
.000\end{array}$ & $\begin{array}{l}.294 \\
.001\end{array}$ & $\begin{array}{l}.355 \\
.000\end{array}$ & $\begin{array}{l}.463 \\
.000\end{array}$ & 1 & \\
\hline IIF6 & $\begin{array}{l}\text { Pearson Correlation } \\
\text { Sig. (2-tailed) }\end{array}$ & $\begin{array}{l}.396 \\
.000\end{array}$ & $\begin{array}{l}.136 \\
.123\end{array}$ & $\begin{array}{l}.163 \\
.064\end{array}$ & $\begin{array}{l}.335 \\
.000\end{array}$ & $\begin{array}{l}.292 \\
.001\end{array}$ & 1 \\
\hline
\end{tabular}

From the Table 9, it can be seen that respondents who accepted long bureaucracy in access international permits from USA embassy was inhibiting factors; also significantly accepted threat of business security in the international market ( $\mathrm{p}$-value $<0.0001$ ), low level of diplomatic relation between Tanzania and USA (p-value < 0.0001 ), weakness of Tanzanian currency ( $\mathrm{p}$-value $<0.0001$ ), rapid price fluctuation ( $\mathrm{p}$-value $<0.0001$ ), and 
higher quality standard established by AGOA (p-value < 0.0001) were inhibiting factors. Respondents who accepted there was threat of business security in the international market they also significantly accepted presence of low level of diplomatic relation between Tanzania and USA (p-value $<0.0001$ ), weakness of Tanzanian currency ( $\mathrm{p}$-value $<0.0001)$, and rapid price fluctuation ( $\mathrm{p}$-value $=0.001)$ were inhibiting factors. But they did not significantly accepted higher quality standard established by AGOA was the factor that hindered local SMEs from accessing this market $(\mathrm{p}$-value $=0.123)$. With these correlation results, the quality standard established by AGOA seemed to have doubtable impact on preventing Tanzanian local SMEs from engaging in AGOA market. But other international factors had significant impact on the matter.

Qualitative findings for this specific objective have been presented as shown below. Cornering rapid price fluctuation and weakness of Tanzania currency it was mentioned that:-

"Tanzania is now witnessing extraordinary price fluctuations and a depreciation in the Tanzania shilling exchange rate, with exchange rate volatility being more evident as it relates to issues of macroeconomic financial stability, impacting the performance of businesses in the nation." (Interviewee 11; Oct 8, 2020).

"Tanzania's exchange rate has been volatile for many years, since the mid of 1980s. Inconsistent of exchange rate together with lack of entrepreneur development policy has lowered the value of products produced by local entrepreneurs......" (Interviewee 12; Oct 8, 2020).

Regarding the higher quality standard established by AGOA interviewees mentioned that:-

"If your products are low in quality compare to the products produced by other entrepreneurs across the world, the product will not sell in European countries and in United States of America." (Interviewee 15; Oct 10, 2020).

“..... The quality they demand our local entrepreneurs cannot easily afford." (Interviewee 2; Sep 14, 2020).

"If one wants to compete better in the USA market; then he/she should be better in quality. Those people are after quality rather than price." (Interviewee 8; Sep 21, 2020).

"I sold my sandals two times in USA under AGOA but high quality standard and regulations became challenges to the reputation of my products. My customers were looking for sandals made with hard materials which are not easily found within our country. So I had to order material from Kenya or Ethiopia. But the benefits became very little then I stopped sending sandals to USA." (Interviewee 5; Sep 15, 2020).

Cornering long bureaucracy in accessing international permits from USA embassy it was stated that:-

"Hardship in obtain USA business visa is not exclusive to Tanzania; it affects the African continent and every third-world country on the planet......African frequently go to the United States as traders, tourists, or scholars, and never return to their own country. Because of the high rate of visa abuse among Africans; obtaining a visa to the United States has become difficult nowadays." (Interviewee 12; Oct 16, 2020).

"Although the application procedure for the United States visa is straight forward and fairly easy, acquiring the visa is more difficult than you would think. It is extremely difficult to obtain a visa, and it is quite expensive; the visa application price is US\$160, and the visa issuance fee is US\$ 50. These are non-refundable costs that must be paid to initiate the process." (Interviewee 3; Sep 15, 2020).

The was interviewee who stated diplomatic relation

“.....business visa given by USA to Tanzanians lasts for only three to six months but to Kenyans lasts for six to twelve months or more. There is no plane moving direct from USA to Tanzania but there is a plane direct from Kenya to USA. All these shown that, diplomatic relationship between Tanzania and USA is not stronger like how it is between Kenya and USA." (Interviewee 9; Sep 27, 2020).

\section{Conclusion}

All examined local factors were found to have significant hindering effect to the Tanzanian SMEs from fully engage in the AGOA market. Base on the order of the main concerning the local hindering factors could be arranged as follows: lack of technological support, poor business policy in the country, low capital and lack of loans to SMEs, long bureaucracy in accessing business permits, poor provision of business information in the country and poor infrastructures in the country.

The international factors that hinder SMEs to fully participate in the AGOA market were identified in the study. Factors that were discovered to highly inhibit the SMEs were rapid price fluctuation, high quality standards, long bureaucracy in accessing the international permits from the USA embassy, and weakness of Tanzanian currency. However, it was also discovered that level of diplomatic relation between Tanzania and USA was not strong to support easy accessibility of this market by Tanzanian SMEs. Lastly the study reported the threat of business 
security in the international market had some little hindering effect to the Tanzania SMEs in accessing AGOA Finally the study concludes that the local and international inhibiting factors were both hindering the Tanzanian SMEs in undertaking the marketing opportunities brought by AGOA market.

\subsection{Recommendation}

There is a great need of revising business in the country so as to cope with the required market. Also to facilitate easy accessibility of the business permit and loans to the SMEs. There was a great need of removing business barriers within the country so as to facilitate easy importation of tools, equipment and machines that are required in processing the raw material into final products.

\section{References}

Adetoso, R., \& Akinseluse, H. (2016). Impact of Internal Audit on Internal Control of Public and Private Universities in Nigeria: A Study on Selected Universities in South West Nigeria. Research Journal of Finance and Accounting, 7(12).

AGOA. (2013). AGOA.info website. Retrieved from http://agoa.info/

Agola, E. (2010). Firmlaunches tax-compliant cash register. Retrieved from http://www.ippmedia.com

Amoafo, S. (2012). Characteristics of SMEs in developing countries. Journal of Small Businesses, 53-83.

Asante, E., Bawakyillenuo, S., \& Ahiadeke, C. (2011). AGOA: Market Opportunity and Supply Capacity in Ghana. Presented in Toward a Transformative Africa Growth and Opportunity Act. Institute of Statistical, Social and Economic Research (ISSER-Ghana).

Brenton, P., \& Hoppe, M. (2016). The African Growth and Opportunity Act, exports, and Development in Sub-Saharan Africa. World Bank Policy Research Working Paper, (3996).

Dzidzornu, A. (2017). Assessing Ghana's Trade under the African Growth and Opportunity Act (AGOA). MPRA Paper No. 84255.

Kazimoto, P. (2014). Assessment of Challenges facing Small and Medium Enterprises. Nairobi: Nairobi University.

Luostarinen, R. (1994). Internationalization of Finnish Firms and their Response to Global Challenges. Research for Action. UNU World Institute for Development Eco-nomics Research, Forssa Printing House Ltd.

Matto, A., Roy, D., \& Subramanian, A. (2012). The Africa Growth and Opportunity Act and Its Rules of Origin: Generosity Undermined? International Monetary Fund Working Paper, 9(13), 56-78.

Msemo, D. (2013). An analysis of strategic factors hindering the performance of Small and medium Enterprises in tertiary industry in Tanzania. Morogoro: Mzumbe University.

Mueller, T. (2018). The effect of the African Growth and Opportunity Act (AGOA) on African exports to the US. Paper presented at the annual meeting of the ISA's 49th annual convention, bridging multiple divides, San Francisco, CA, USA .

Opoku, M. (2016). Extending African Growth and Opportunity Act (AGOA) beyond September 2015, what is at stake for Ghanaian entrepreneurs and participating companies? Nkuruma University.

Osei-Assibey, E. (2015). Export Promotion in Ghana. Retrieved from http://www.acetforafrica.org

Seyoum, B. (2017). Export performance of developing countries under the Africa Growth and Opportunity Act experience from US trade with Sub-Saharan Africa. Journal of Economic Studies, 34(6), 515-533. https://doi.org/10.1108/01443580710830970

World Bank. (2016). Trade Preferences and Differential Treatment of Developing Countries. Policy Research Working Paper 3566, Bernard Hoekman.

Yahya, K., \& Mutarubukwa, J. (2015). Regional Cooperation and The Role of International Organizations and Regional Integration. Tanzania: Mkuki na Moyo Publishers.

\section{Copyrights}

Copyright for this article is retained by the author(s), with first publication rights granted to the journal.

This is an open-access article distributed under the terms and conditions of the Creative Commons Attribution license (http://creativecommons.org/licenses/by/4.0/). 